\title{
Verbalised stereotypic beliefs about Ruthenians in the German-language literature of Austrian Galicia and its Ukrainian translations
}

\author{
Roksoliana Stasenko ${ }^{1}$ \\ ${ }^{1}$ Ivan Franko National University of Lviv, Universytetska St., 1, 79000 Lviv, Ukraine
}

\begin{abstract}
This article presents the ways to verbalise the stereotypic beliefs about Ruthenians, considering linguistic and extralinguistic factors. The study is based on the German-language literature, namely of works of Alexander von Guttry, Salcia Landmann, Leopold von Sacher-Masoch and Karl Emil Franzos written during the period of the Kingdom of Galicia and Lodomeria (1772-1918), or simply Austrian Galicia. The selection of works was carried out according to the following criteria: Germanlanguage source text, time of writing the work, its plot, existence of Ukrainian translation in the postmodern era. The stereotypes about Ruthenians were singled out using the keywords Ruthene, ruthenisch, Ukrainer, ukrainisch, русин, русинський, украӥнець, український. Тhe stereotypes themselves are considered as simplifying ideas about the character, appearance, daily life, habits and traditions of a certain social group, in this case - the Ruthenians as one of the largest ethnic groups in Austrian Galicia. The implementing of Ruthenians stereotyping are represented on the level of lexis and grammar, context and discourse. The research results show that stereotypes about Ruthenians tend to have negative connotations, which is primarily due to their miserable situation in the Empire. However, the authors fondly described the positive qualities of the Ruthenians' character, such as hospitality, talent for singing, kindness. Within the framework of a cultural approach in translation studies, which takes into account the cultural, social and historical factors of writing the source and target texts, the ways of verbalising the Ruthenians stereotyping in modern translation are examined.
\end{abstract}

\section{Introduction}

Translation, as a special form of communication between peoples, ethnic groups and cultures through the ages, reflects all the social factors and preconditions under which the source text originates and is transcoded into another language. During the relatively short history of its existence, translation studies have repeatedly undergone reorientation: from linguistic and sociolinguistic approaches to communicative ones, from hermeneutic and semiotic to cognitive-psychological. Because of globalisation processes and the rapid

\footnotetext{
${ }^{1}$ Corresponding author: roksoliana.stasenko@gmail.com
} 
development of telecommunication, nowadays translation is considered primarily as an act of intercultural communication, which enables communication between different cultures. Of course, as the most common way of human communication language plays the main role in this process. However, as the translation scholar J. House points out: "Language is culturally embedded: it serves to express and shape cultural reality, and the meaning of linguistic units can only be understood when considered together with the cultural contexts in which they arise, and in which they are used." [1] For these reasons, modern scholars treat translation not only as a linguistic transfer, but also examine the full range of nonlinguistic factors involved in the translation process, such as cultural and historical background of the source text, the identity of the author of the source text and the translator's role in the target culture.

This cultural approach is due to the cultural turn that developed in the 1990s as an aspect of functional translation studies and is primarily associated with the names of such scholars as Susan Bassnett and André Lefevere (1990), Lawrence Venuti (1995), Juliane House (2015). S. Bassnett and A. Lefevere proposed to study translation in context as a fact of history and a product of the target culture, rather than as a common and habitual comparison of language units and their differences in the source and target languages [2]. Translation, according to the authors, should function as a way of a culture building due to which relatively young peoples have the opportunity to express their identity in the environment of more influential neighbouring states. In addition, it should make it possible to reveal the images of authors and entire cultures hidden in the original texts [2]. In the framework of functional translation studies researchers K. Reiß and H. J. Vermeer propose to consider the purpose of translation as a transfer between cultures: "The translator (as a translator) is not interested in objective reality or truth values. The translator is interested in the value of a historical event as it manifests itself in a text, in relation to the applicable norm (culture) and current situation of the text (and / or its producer) and the change in value when the text is translated into a target text." [3] Translation scholars point out that the translator should not be interested in the transmission of reliable information, but in the transformation of the source text in accordance with the readership expectations in the target culture.

Cultural turn as a theoretical and methodological shift in translation studies is a good basis for the study of cultural stereotypes - simplified, standardised and emotionally coloured beliefs of the cultural community about the representatives of certain peoples. Like any other phenomenon of the objective world, they are realised in language, but behind such linguistic signs a whole range of extralinguistic factors is hidden, especially the peculiarities of relations between different peoples, which have developed over the long history of their existence. As part of the study of the verbalised ethnic stereotypes translation, a cultural approach allows us to explore images and ideas that are not explicitly expressed in the text, and to identify possible deviations in the perception of these images in the target culture.

In today's world, the relevance of the study of ethnic stereotypes is not in doubt, because they govern most international relations, and in particular conflict situations. At the stage of Ukraine's formation as an independent state and its identification in the world, it is interesting and at the same time extremely essential to examine how Ukrainians were perceived by representatives of other cultural communities, how such ideas were formed and how they were transmitted by language. An equally important issue is the study of the ways to translate such verbalised stereotypes into modern Ukrainian. This article aims to consider the linguistic means of implementing stereotypical beliefs about Ruthenians (the name of Ukrainians used in Western Ukraine until the twentieth century) in Germanlanguage literature, which arose and existed in the period of the Kingdom of Galicia and 
Lodomeria (1772-1918) as the biggest crown land of Austria and later of the AustroHungarian Empire (in particular in the works of Alexander von Guttry, Salcia Landmann, Leopold von Sacher-Masoch, Karl Emil Franzos) and to explore the tactics of their translation for the modern Ukrainian readership in view of cultural, historical and social factors.

\section{Research methods}

The research methodology is based on the principles of anthropocentrism, interdisciplinarity, ethnocentrism and on the cultural approach to the analysis of the linguistic means of representation of ethnic stereotypes in the German-language texts and their reverbalisation in the Ukrainian language with the aim of investigating their essence, cultural specificity, and influence on the target recipients. First, the analysis of scientific definitions (to define and interpret the concept of stereotype) and a brief overview of the study of stereotypes in sociology as well as in linguistics are presented.

In the scientific literature, stereotypes are defined as "beliefs about the characteristics, attributes, and behaviours of members of certain groups" [4]. Such groups can be characterised by different categories, such as nationality, religion, gender or age. Ethnic stereotypes are the main focus of this article, for which we find the following definition:

Representations of a group identified by an ethnic label [...] which reproduce the most frequently represented traits associated with such groups. Selective perception or salience tends to reinforce such stereotypes by drawing attention to examples confirming it and blinding the observer to individual differences. [5]

Stereotypes were originally used in the publishing sphere to denote special forms of prints, through which it was possible to achieve large number of printed copies. In the 20th century, stereotypes were adopted in the fields of sociology, psychology, ethnology, linguistics and cognitology. Repetition and frequent use have become a metaphor for a stereotype in a new sense. American journalist and publicist W. Lippmann, a pioneer in the development of the science of stereotypes, defines them as mental concepts, images in our heads that serve to simplify and save effort to explore something new. According to him, the modern world is characterised by haste, so we do not have time to delve into details we usually notice only one feature of the object and the rest are supplemented by stereotypes [6]. Summarising the results of research by other scholars, J. Gilmour cites aspects that influence the formation of stereotypes, namely: coordination of goals, observation of facial features to identify age, gender and race, activation of knowledge about the cultural community, gained through the media, social belief and imagination [7].

Stereotypes, like any other phenomena of the objective world, are implemented by the means of language. The process of transmitting stereotypes through language is quite complex, because a few words, sentences or text passages must contain all the knowledge about a particular social group, formed over a long period of time in the collective consciousness. However, in the case of national or ethnic stereotypes, usually only one ethnonym, such as German or Jew, is enough to activate all background knowledge about the members of this community. In this case, ethnonyms work as signs, forcing us to turn to semiology. German researcher H. H. Hahn describes stereotypes from a semiological point of view as special signs for the collective designation of a certain object (in our case a group of people or its representatives), which consist of three elements - perception, attribution, and emotional connotation - and which are always parts of sign systems, i.e. they cannot exist in the mental and social world separately from each other [8].

Regarding the formal expression of stereotypes, there is still no clear structure in the scientific literature. German linguist U. Quasthoff believes that stereotypes are realised primarily in the form of sentences with different perspectives of stereotyping (for example: 
I believe that Germans are...; We were told that Germans are...), as well as at the discursive level that requires additional knowledge to understand a particular stereotype [9]. O. Falafivka proposed the classification of ethnic stereotypes representation, distinguishing their primary language markers and the aids for their verbalisation. Into the first group the researcher includes ethnonyms and their derived adjectives and adverbs, toponyms and words derived from them, anthroponyms, colour names, religions, names of well-known national symbols, values and realities. The second group includes phraseologies, stylistic devices, implicit means, constant phrases, proverbs and sayings [10]. H. J. Heringer believes that stereotypes can be recognised among other expressions in the text with the help of so-called "search masks", which may consist of the name of the group we are looking for, verbs to be, to do, should, adjective typical, adverbs always, constantly, pronouns all, these, all these [11].

To identify and substantiate the means of ethnic stereotypes representation that have an established valency, this study used a combined semantic-structural method. The distribution method is used to identify the peculiarities of word compatibility to denote ethnic stereotypes in German and Ukrainian, and the contrastive method is used to compare the peculiarities of implementation and structural elements of ethnic stereotypes about Ruthenians in German and Ukrainian. In the present research, both primary language markers of ethnic stereotypes, namely of Ruthenians, and their syntagmatic and contextual implementation are considered. The study used the works written by German-speaking authors who lived in the Habsburg Kingdom of Galicia and Lodomeria (1772-1918), who were natives of this region, travelled across or worked in its territory and shared impressions of their experiences in their numerous literary and journalistic works. A key aspect in the selection of works was the question of whether the mentioned Germanlanguage works were translated into Ukrainian in the postmodern era, i.e., for the modern Ukrainian readership. The search for stereotypes about Ruthenians was carried out using the keywords Ruthene, ruthenisch, Ukrainer, ukrainisch, русин, русинський, українещь, український (typical ethnonyms to denote the Ukrainian people in the 18th-20th centuries and the adjectives derived from them). To explain the functioning of ethnic stereotypes in synchrony, i.e., in the period of Austrian Galicia (1772-1918) and in the period of their verbalisation in Ukrainian-language texts - starting from the 21 st century, the descriptive method is applied. The contextual method was used to establish the levels of verbalisation of ethnic stereotypes in German-language texts, examining linguistic, situational and culturological dimensions.

As for the translation of linguistic means of ethnic stereotypes realisation, they have not been the subject of research in the German-Ukrainian language pair in the field of Ukrainian translation studies yet. This determines the relevance of this article. Ukrainian translations of verbalised stereotypes about Ruthenians are analysed within the framework of a cultural approach in translation studies, which defines translation as a transfer between cultures, as a special form of rewriting. Cristina Marinetti emphasises that "translation is one of the ways in which works of literature are 're-written', and these re-writings are the primary way in which cultures construct 'images' and 'representations' of authors, texts and entire periods of history" [12]. To reconstruct such images, it is necessary to involve in the analysis not only such classical categories of translation as the original or equivalence, but also cultural transformations, variability, cultural differences and power [13]. Because ethnic stereotypes as mental constructs are deeply ingrained in the culture of a particular people, their verbalisation takes place in view of the values and heritage that are specific to a particular cultural community.

If we take into account the fact that in the framework of a cultural approach the translated text will be subject to change due to cultural, historical and social needs and requirements of the target culture, we can hypothesise that stereotypes about Ruthenians 
verbalised in the works of German-speaking authors in Austrian Galicia will inevitably be restructured and rethought in modern Ukrainian translations, as the Ruthenian people have gone through and still go through a long and difficult path of forming their own identity in the international space, which requires a constant struggle for dignity and recognition of this ethnic group in the world. Therefore, translators will act as mediators between the two cultures and will intervene in the words of the author of the original work to ensure the maximum approximation of the original text to the modern Ukrainian readers.

\section{Research results}

The Kingdom of Galicia and Lodomeria was formed as a result of the First Partition of Poland in 1772 as a new administrative-territorial unit within the Habsburg Empire. It covered the territory between the Polish cities of Kraków, Tarnów and Przemyśl (modernday Eastern Poland) and the Ukrainian cities of Lviv, Kalush and Ternopil (modern-day Western Ukraine). Today the largest crown land of the Empire, which existed until 1918, is rarely associated with a multicultural, multilingual, polyethnic historical landscape. At that time, it was called "Halb-Asien" (Semi-Asia, the title of a book written by a Germanspeaking writer from Galicia Karl Emil Franzos), an exotic country of bears, a wild region far from the capital of Vienna, where robbers hid [14]. Galicia (shortened name of the Kingdom) existed in the minds of Empire citizens as a stereotype of "poor European house", where, in addition to everyday difficulties and arbitrariness of officials, quarrels among the population and lack of prospects determined the existence of mostly rural population [15].

As for the population of Galicia, it consisted of three large ethnic groups, which differed greatly from each other: Ukrainians, called Ruthenians, Poles and Jews, which were complemented by some other smaller groups like Germans, Armenians and other. In 1851, the census showed 4.5 million inhabitants, by 1910 that number had risen to 7.5 million. $58 \%$ of the Galician population were Poles, who usually were feudal lords and small traders, $40 \%$ were Ruthenians, who inhabited mostly rural areas, and $12 \%$ were Jews, who have always been in the spotlight because of their "otherness". The writer Salcia Landmann emphasised the sharp contrast between the representatives of different ethnic groups, writing the following: "In this country, despite close economic ties, Poles, Ruthenians and Jews lived together, but culturally separated from one another like oil and water" [16]. Cultural differences between ethnic groups were based mainly on their religious denominations, which largely determined the daily life, habits, customs and behaviour of the population. In Galicia, a distinct variety of denominations was presented: "The diversity of churches and denominations represented in the crown land was as colourful as the ethnic composition of the population. [...] Roman Catholics lived in close proximity to Greek Catholics and Orthodox Christians, to Jews and Protestants of various denominations, to Karaites and believers of the Armenian Uniate Church." [15] Thus, the Galician population was an interesting and at the same time complex construct, where people of different cultural, language and religious origins lived in a relatively small area. In general, Galician society was described as follows: agrarian property, mostly in the hands of the Polish nobility, on the one hand, and poverty on the other, Polish-speaking farmers in the west of the province and Ukrainian-speaking in the east, as well as Jewish village craftsmen, tenants of inns and small traders [17].

An interesting question is why among the Slavs in Eastern Europe there appeared a relatively large number of German native speakers, as until 1772 there was no German cultural tradition at all (by 1786 about 3097 families moved to Galicia). Maria Kłańska, a Polish researcher of Galician literature, explains this fact as follows: 
The Germanised administrative apparatus, the educational and judicial systems offered German-speaking officers, teachers, and scholars the opportunity for a worthwhile professional career. Added to this, there were the needs of the army, which set up its posts in numerous garrison towns in the occupied country. The impoverished German farmers from the Palatinate, Hesse and Swabia were lured to Galicia by an extensive advertising campaign by Joseph II with many privileges. The urban colonisation was also supported by the House of Habsburg, so that many merchants, craftsmen, entrepreneurs and representatives of the liberal professions settled in Galicia. [18]

The existence of a German-speaking population on Slavic territory gave rise to the socalled "German-speaking literature of Austrian Galicia". The authors of this literature were natives of the Habsburg crown land Kingdom of Galicia and Lodomeria, lived in this region or travelled across its territory and shared impressions of the social-cultural life of the land in their numerous notes, diaries, essays, stories and novels. According to Yu. Prokhasko, the purpose of such writings lies in describing, classifying and comparing aspects of life in the newly formed territorial unit, as well as in satisfying the curiosity of the readership in the German lands. In addition, such literature has left the most crucial effect - it has led to the formation of several clichés and stereotypes about Galicia [19]. In their works, the authors of German-language Galician literature usually directly address the Germanspeaking, "European" readers, emotionally and somewhat exaggeratedly informing them about things unknown to Western people. Among such reports, there are many ethnic stereotypes that describe the population of Galicia in a simple and emotional way. The analysis of ethnic stereotypes about Ruthenians is relevant for this article, which will be presented in the next part of the study. Such authors, whose works will be analysed in this article, were four German-speaking writers Alexander von Guttry Salcia Landmann, Leopold von Sacher-Masoch and Karl Emil Franzos. The analysis includes five culturological essays by these authors with a total volume of 675 pages of original and translated texts, which were written during the existence of the Kingdom of Galicia and Lodomeria, although they were published outside its territory. It should be emphasised once again that these are only those works in which the authors described the character, appearance and daily life of the Ruthenian people, and which are translated into Ukrainian in the postmodern era: A von Guttry "Die Polen. Die Ruthenen. Die Juden" (Ukranian translation by I. Klym, A. Paslawska), S. Landmann "Mein Galizien" (Ukrainian translation by P. Rykhlo), L. von Sacher-Masoch „Don Juan von Kolomea“ (Ukrainian translation by N. Ivanychuk), „Am Dniester“ (Ukrainian translation by Kh. Velyka, Yu. Prokhasko), K. E. Franzos „Markttag in Barnow“ (Ukrainian translation by P. Rykhlo).

First, the variants of using ethnonyms as primary lexical markers of ethnic stereotypes in the source and target texts will be presented. During the existence of Galicia, the western Ukrainian population was called Ruthenen in German, which is borrowed from Latin. Most Ruthenians lived in archaic conditions, having no contact with the wave of social and economic modernisation that swept the western parts of the empire [20]. Therefore, stereotypes about Ruthenians usually contained information about their poverty and difficult life: "Heute sind die Ruthenen einer der unglücklichsten, zertretensten Volksstämme auf Erden.” [21] - writes the Austrian writer, a native of Galicia, Karl Emil Franzos in the work "Markttag in Barnow". The author combines the ethnonym with negative connotative adjectives used in the form of a superlative, which provides the statement with exaggeration and emotion. In the target text we find the full lexical equivalent of this stereotype without any linguistic changes to what is written: "Сьогодні русини є одним з найнещадніших, найпригнобленіших племен на землі." [22] The only difference between the original and the translation in this case is its perception in the source and target cultures. The adverb heute (today) emphasises the current state of events that 
prevailed at the time of writing. However, the modern Ukrainian reader would rather be dissatisfied with such a statement of the fact and would not agree with the words of the author. Another example of a combination of ethnonyms and descriptive adjectives to inform about the character of Ruthenians can be found in the work of A. von Guttry "Die Polen. Die Ruthenen. Die Juden": "der Ruthene [ist] langsam und überlegt, misstrauisch, argwöhnisch und verschlossen, zugleich aber doch auch leichtgläubig und unbeholfen" [23] - "русин є неквапливим та розсудливим, недовірливим, обачним та потайливим, але разом з тим щирим та безпорадним” [24]. The author uses several adjectives to describe the typical character traits of the Ruthenians. As in the previous example, there are no visible changes applied to the translation, but the perception of the stereotype also differs, because the verb to be is used in the original in the present tense, which also emphasises the actuality of events and may not correspond to today's reality.

Leopold von Sacher-Masoch, an Austrian writer and a native of Galicia, uses the ethnonym Russen in his work "Don Juan von Kolomea" to denote the Ukrainian people of Galicia: "Wir Russen erzählen gerne und lassen uns gerne erzählen.” [25]; "Ein Russe, das hatte er gleich gesagt, und war auch nicht schwatzhaft genug, um für einen Polen gelten zu können." [25] In the first example, the author uses an autostereotype - a vision of a particular social group itself, which is expressed in the personal pronoun wir (we). M. Thiele believes that autostereotypes tend to emphasise the positive qualities [26], which is clearly shown in the first example. In the second example, the author applies the stereotype of the Ruthenians, comparing it with the neighbouring people - the Poles. In both cases, the ethnonym Russe( $n$ ) is used, which in modern German corresponds to the word Russian(s). Apparently, the author used this term as derived from the word Rus', a historical territory in Eastern Europe inhabited by Eastern Slavs. However, the competent translator N. Ivanychuk rendered this ethnonym in Ukrainian as русини (Ruthenians), which demonstrated her awareness of the then historical and cultural background: "Ми, русини, охочі до розповідей, але й охочі слухати розповіді інших." [27]; “Русин - про ие він одразу ж сказав, та й не такий балакучий, щоби прийняти його за поляка.” [27] In these two examples we can speak about cultural and historical analogues in the source and target languages. In the same work, the author uses another ethnonym, namely Kleinrussen (Little Russians), to describe the Ukrainian inhabitants of Galicia: "Das ganze östliche Galizien vom San an, ist vorwiegend von Kleinrussen, drei Millionen bewohnt, welche der unirten [sic!] griechischen Kirche angehörten.” [25] In the German online lexicon, we find the definition of the ethnonym Kleinrussen - a Russian-Slavic tribe in southern Russia, Eastern Galicia, and North-Eastern Hungary, which differs from the Great Russians in customs, way of life and language [28]. Due to historical events and as a consequence of the formation of an independent Ukrainian identity, the term Little Russians is today considered as chauvinistic, offensive and unacceptable in Ukraine. To avoid misunderstandings in conflict situations between the author and the reader of the work, the translator used the neutral ethnonym українці (Ukrainians), thus applying the strategy of corrective translation: "Уся Східна Галичина, починаючи від Сяну, заселена здебільшого україниями, чисельністю до трьох мільйонів мешканиів, які належать до уніатської греко-католицької ичеркви." [27]

The Swiss writer from Galicia, Salcia Landmann, also uses the ethnonym Ruthenen, which the translator instead transmits as украӥниі (Ukrainians), thus, adapting the translation as close as possible to the modern Ukrainian readers: "Auch daß es nicht den Juden, sondern den Ruthenen hier in Ostgalizien damals am schlechtesten ging, verzeichnet der Reiseführer getreu und erwähnt, daß die Ruthenen meist Bauern, oft landlos und häufig Analphabeten waren." [16] - “Те, що у Східній Галичині найгірше велося тоді не євреям, а українцям, путівник також зазначає, нагадуючи, щь украӥнці були переважно селянами, часто безземельним і неграмотними." [29] This stereotype 
contains information about what the Ruthenians did in their daily lives and about their miserable situation in general. In this example, the stereotypical representation is reinforced by three adverbs of frequency meist (most of time), oft (often), häufig (frequently). In translation, we see that the third adverb was left out, which reduces the emphasis on the repetition of facts and somewhat eliminates the negative features of the Ruthenians. Due to these adverbs, the stereotype is also verbalised in the form of generalisation considering all members of the ethnic group.

Not all stereotypes about Ruthenians used in the German-language literature of Austrian Galicia are negative. Despite the fact that the Ruthenians lived quite poorly, they differed in their positive character traits, as we can see in the examples from the work "Am Dniester" by L. von Sacher-Masoch: "Die Gastfreundschaft ist eine Leidenschaft der Ruthenen und der einfachste Landmann übt sie mit einem Takte, den man in Norddeutschland bei dem Vornehmsten übel vermisst." [30]; "Gutmütig ist der Ruthene im höchsten Grade, so dass er selten etwas nachträgt, und nach der grössten Bedrückung doch nie Rache zu nehmen sucht." [30] To emphasise such positive qualities of Ruthenians as hospitality or kindness, the author reinforces stereotypes with many superlatives. Translators seems to like the author's idea to reinforce positive traits of their historical ancestors and use them even more often than in the source text: "Гостинність - ие справжня пристрасть русина, $i$ навіть простий селянин виявляе ї̈ з таким тактом, якого годі шукати навіть у найвельможніших домах Північної Німеччини.” [31]; “Добросердність русина не знає меж, так що він анітрохи не злопам'ятний, не прагне помсти навіть за найбільшу кривду." [31] In the original, we find the phrase Leidenschaft der Ruthenen (passion of Ruthenians), which is supplemented in translation by the adjective справжня (real). The author of the source text also states that Ruthenians are rarely spiteful, and in translation the adverb selten (seldom) was changed to анітрохи (not a bit). Such a translation somewhat modifies the author's words, as seldom is not the same as not a bit. It is also interesting to note that in the above-mentioned examples the author uses the ethnonym Ruthenen, although in other works he resorts to the use of the terms Russen (Russians) and Kleinrussen (Little Russians). From this we can conclude that the author did not think much about the images of Ukrainians he creates and called them rather ill-considered. Another example of integrating positive traits into a stereotype by the method of generalisation is an example from the work of K. E. Franzos: "unter den Russinnen singt jeder und dichtet fast jeder” [21] - “адже серед русинів співає і віриує майже кожен” [22]. In the original, the author uses the indefinite pronoun jeder (each) twice: once with the verb singen (to sing), and once with the verb dichten (to write poetry), supplementing it with the particle fast (almost). However, the translator decided to reinsure himself, and not to make a too broad generalisation about the singing talents of Ukrainians. Therefore, he used only the form майже кожен (almost each) with both verbs.

Linguistic implementation of the stereotypes about Ruthenians is done not only on the level of lexical or grammatical, but also stylistic devices of speech. One of such tool is comparison. Authors of German-language literature in Austrian Galicia often compared the Ruthenians to the Poles who lived and worked nearby. A. von Guttry compares the Ruthenian hospitality, which has already been mentioned in this article, with that of the Poles: "Auch der Ruthene hängt mit äusserster Zähigkeit am Alten, und auch die Gastfreundschaft gehört, wie bei den Polen, zu seinen Haupttugenden." [23] - "Pycuн теж глибоко шанує традицію. Гостинність, як $i$ в поляка, належить до його головних чеснот." [24] We see that in translation the plural form of the noun Polen (Poles) has been changed to the singular form поляк (Pole), which establishes a certain connection between a Ruthenian and a Pole as selective representatives of their ethnic groups. L. von Sacher-Masoch also compares the positive character traits of the Ruthenians with the character of the Poles: "Im österreichischen Heere gilt der Ruthene, ebenso wie 
der Pole, mit einem Worte, der galizische Soldat als der beste, ausdauerndste und verlässlichste." [30] - “В австрійському війську русина, так само як поляка, словом, галииького солдата вважають найкращим, найвитривалішим і найнадійнішим.” [31] In this example, the writer combines several ways of realising ethnic stereotypes, namely ethnonyms, comparisons, superlatives and generalisations (he unites a Ruthenian and a Pole in one word - a Galician soldier). There are no special lexical or grammatical changes in the translation of the mentioned example. When using the ethnonym Ruthenian, the authors usually mean the average, generalised representative of the ethnic group of Ruthenians, which, according to the research results, belongs to the masculine gender. When it comes to women, the authors usually use additional stereotypes, which imply that the information concerns the women. The following example from the work of L. von Sacher-Masoch demonstrates the peculiarities of the use of such a "female stereotype" along with the stylistic comparison: "Insbesondere sind die ruthenischen Frauen oft von ausgezeichneter Schönheit, gleich den Polinnen mit reichen, meist dunklen Haaren und seelvollen Augen ausgestattet." [30] - "Особливо руським жінкам притаманна незрідка просто-таки виняткова врода, оздоблена, так само як $i$ в польок, густим, темним волоссям $i$ промовистими очима." [31] We do not see any lexical or grammatical changes in the translation, but we do see that the ruthenische Frauen (Ruthenian women) are translated as руські жінки (women of Rus'), but not as русинські жінки (Ruthenian women), which expresses a greater connection with women in the historical territory of Rus' than with women from Galicia.

In addition to the stylistic means of comparison, the authors also use the technique of antithesis which arises through the opposition of two concepts that are on the same logical level [32] to compare representatives of different ethnic groups and their main features. An interesting example is a comparison of a Ruthenian with a Galician German by K. E. Franzos:

Der Ruthene ist träg, der Deutsche überaus fleißig. Der Ruthene liebt den Schnaps sehr, der Deutsche trinkt am Sonntag sein Gläschen Meth oder Wein und sehr selten ein Glas über den Durst. Der Ruthene ist kein guter Rechner, der Deutsche ist sparsam bis zum Geiz; der Ruthene ist vertrauensvoll und läßt sich darum leicht vom Polen oder Juden betrügen, der Deutsche ist mißtrauisch, vorsichtig, reell, borgt niemand und läßt sich überhaupt, aktiv wie passiv, nur überaus ungern in Geldgeschäfte ein; der Ruthene ist schmutzig, der Deutsche sauber; der Ruthene ist gern Landwirt und Viehzüchter zugleich; der Deutsche wirft sich auf irgend eine Spezialität und hält sie fest: er züchtet Kälber oder er baut Gemüse $u$. dgl. Darum ist Deutsche wohlhabend, während der Pole und Ruthene mit harten, materiellen Nöten ringt. [21]

The author contrasts the character, habits and daily activities of Galician Ruthenians and Germans. Unfortunately, most of the features of the Ruthenians also have a rather negative connotation, while the Germans are credited with the best virtues. Here the identity of the author is manifested, as he, being a native of Galicia, considered himself a conscious German all his life, because his father taught him to love everything German and brought him up "in the spirit of admiration for German culture and language" [33]. Therefore, the Germans appear in the works of K. E. Franzos mostly in a positive light. In the target text, the translator remained faithful to the author and did not make any special changes to his words. However, we can predict the reaction of the Ukrainian reader, who, obviously, will not be satisfied with the following description:

Позаяк русин інертний, а німещь надзвичайно старанний. Русин дуже любить горілку, а німець випиває в неділю свою склянку меду або вина й лише зрідка ще щзось, аби вгамувати спрагу. Русин не надто великий рахівник, натомість німець економний аж до скупості. Русин довірливий, а тому дає 
себе легко обдурювати полякові чи євреєві, німець - недовірливий, обережний, чесний, ніколи ні в кого не позичає $i$ взагалі дуже неохоче ув'язується, активно чи пасивно, у фінансові тешефти. Русин брудний, німець чистий. Русин нерідко водночас займається як рільництвом, так $i$ тваринництвом, німець зазвичай віддається якійсь певній сфері й міџно тримається ї̈: він розводить телят або вирощує овочі або вдається до чогось подібного. Тому німеиь заможний, в той час як поляк чи русин живуть у важкій матеріальній скруті. [22]

It is also interesting to observe how German-speaking authors from Galicia verbalise the specific relations of Ruthenians with various neighbouring ethnic groups. Apparently, the Ruthenians were friendly to the Austrians, who annexed their territory, but improved the conditions of their social life by separating them from the Poles. K. E. Franzos integrates this fact into the following stereotype: "Denn durch den Österreicher sind wir erst Menschen geworden', sagt der Ruthene und vom Sohn auf den Enkel vererbt er die Dankbarkeit gegen den Staat, welcher ihn dem polnischen Adel und damit der grauenhaftesten Sklaverei entrissen.” [21] - “Тому щуо лише завдяки австрійцям ми стали людьми', - каже русин, і від сина до внука успадковується вдячність державі, яка вирвала його з рук польської шляхти, а заодно і з найжорстокішого рабства." [22] In translation, the neutral phrase polnischer Adel (Polish nobility) is translated as a historical term польська шляхта (Polish szlachta), as almost every Ukrainian knows that szlachta was a class in Poland, which enjoyed many privileges in society. This provides the information with more expressiveness, and the understanding of the Ukrainian reader with more compassion for their ancestors from the past. Another example through which the author informs about the relations of Ruthenians with other peoples is as following: "Darum liebt und hegt der Ruthene seine Hunde sehr und gibt ihnen oft die saftigsten Namen, zum Beipsiel: 'Liach' oder 'Moskal'.” [21] - "Тому русин дуже любить і плекає своїх собак $і$ зазвичай дає їм найсоковитімі імені, наприклад, 'Лях' або 'Москаль..', [22]. In "love" for dogs, the "love" for Poles and Russians is actualised (Liach is the historical name of a Pole, which due to complex Polish-Ukrainian relations has acquired a negative character and is now not used in official vocabulary, Moskal is a contemptuously ironic name for a Russian). Although the translator did not make significant changes during the translation, the perception of this stereotype differs greatly in the source and target cultures, because for German-speaking readers such ironic designations of peoples obviously inform only about their existence, but for the Ukrainian reader they encourage the development of several additional emotional connotations.

\section{Discussion}

The German-language literature of Austrian Galicia was a wide field for describing the typical features of the Ruthenians as one of the largest ethnic groups in the crown land in the Habsburg Empire. After spending only a short time in the Kingdom, the authors could not see the whole picture of Ruthenians' life, so they often supplemented the experience with their own beliefs. Unfortunately, most of the stereotypes about Ruthenians used at that time have a negative character, although the authors' sympathy with this unfortunate, oppressed people can be traced. However, despite the poor social status, writers still found positive qualities of Ruthenians and mentioned them in their works. They also fondly described the relations of Ruthenians with other peoples that have developed historically.

So how the linguistic implementation of the stereotypes about Ruthenians is done? In this study, stereotypes were analysed primarily as syntagmatic units (according to $U$. Quasthoff [8]). The semantic-structural method helped to reveal a more or less stable 
valence of stereotype units, namely: ethnonym in the singular or plural + verb, usually in the present tense to emphasise the actuality of events (because all analysed works were written and addressed to the German-speaking reader in synchronism) + a set of features in the form of secondary parts of the sentence. The verbalisation of the stereotype begins already at the level of ethnonyms and, as the examples have shown, already at this stage many debatable issues have arisen regarding their translation in the Ukrainian language. While the German-speaking authors were more indifferent to whether the Ruthenians would be called Ruthenians, Russians, Little Russians, or Ukrainians, for the modern Ukrainian-speaking reader the translators chose the most appropriate notation so as not to offend his identity. Therefore, the analysis of the social-cultural significance of stereotypes in the source and target cultures plays a key role in the study of the verbalisation of ethnic stereotypes.

A popular way to verbalise stereotypes are grammatical and sometimes lexical forms of superlatives, which exaggerate and emotionally emphasise the positive or negative qualities of Ruthenians. Superlatives for negative characteristics are not always translated by Ukrainian translators, while superlatives for positive qualities sometimes appear more often than in the original. Due to stylistic means of comparison and antithesis, the writers revealed about the typical relations of the Ruthenians with other peoples and compared them. Examples have shown that Ruthenians were often compared to Poles as two Slavic peoples in Galicia. Such stereotypes tend to describe positive qualities. Instead, the comparison of the Ruthenian with the German showed a sad reality and presented them in a rather negative light. It was also interesting to trace the verbalisation of the stereotypes about Ruthenians at the contextual level. Usually, such stereotypes are not transmitted directly, but veiled, so it requires not only to know the plot of the work, but also to have knowledge of extralinguistic, social-cultural factors to understand them.

\section{Conclusion}

Ethnic stereotypes describe in a simplified and reduced way the representatives of a certain ethnic group, their traits, habits, professions, appearance and relations with other peoples. Analysing the works of four German-speaking writers who were born in Galicia (S. Landmann, L. von Sacher-Masoch, K. E. Franzos) or travelled across its territory (A. von Guttry), we can see the whole picture of the daily life of its inhabitants, who belonged to different ethnic groups. For the current state of development of science, it was interesting to obtain information about the Ruthenians as representatives of the Ukrainian peoples in the western Ukrainian territory. Such information is crucial for understanding how Ukrainians were perceived in the past and how such beliefs influenced the formation of relations with this people in the present. As we know, Ukrainians do not stop fighting tirelessly for the recognition of their own identity in the international space. Some negative stereotypes about Ruthenians date back many centuries, as evidenced by the analysed examples from the works of the 19th century. From the stereotypes presented in the article, we see that even at that time Ruthenians were endowed with many negative qualities. In addition, the authors often mention the plight of this people, although the Ruthenians themselves were happy to be under Habsburg rule. In order not to injure and upset the modern Ukrainian reader with information about his ancestors, translators skillfully applied translation changes and corrected the author's words where possible and necessary. The hypothesis presented in the methodological part of this article that verbalised stereotypes will be transformed, as we speak about the translation of culturally marked units, has been confirmed. The postulates of culturally oriented translation studies presuppose the impossibility of considering the source and target text on the basis of its interrelation alone. According to L. Venuti, the translator must play a key role in the global circulation of 
culture to reveal the invisibility of cultural values, and at the same time the linguistic differences between the source and target cultures [34]. Therefore, the translation of verbalised stereotypes can and should be modified according to the needs and expectations of the target readers, if it is a stereotype of one's own ethnic group, so that translation is a product of historical and social epochs but not a marginalised interlingual transfer.

\section{References}

1. J. House, Translation Quality Assessment. Past and present (Routledge, London, 2015)

2. S. Bassnett, A. Lefevere (eds.), Translation, History and Culture (Pinter, London, 1990)

3. K. Reiß, H. J. Vermeer, Grundlegung einer allgemeinen Translationstheorie, 2 Aufl. 1991 (Niemeyer, Tübingen, 1984)

4. J. L. Hilton, W. von Hippel, Annu. Rev. Psychol., 47, 237-271 (1996)

5. Oxford Reference, Ethnic stereotypes. URL:

https://www.oxfordreference.com/view/10.1093/oi/authority.20110803095759563

6. W. Lippmann, Public Opinion (Transaction Publishers, New Brunswick and London, 1998)

7. J. Gilmour, Behav. Scien. Undergrad. Journ., 2(1), 67-73 (2015)

8. H. H. Hahn, Stereotypen, Vorurteile, Völkerbilder in Ost und West in Wissenschaft und Unterricht - Eine Bibliographie, 2, XI-XVII (2008)

9. U. Quasthoff, Soziales Vorurteil und Kommunikation - Eine sprachwissenschaftliche Analyse des Stereotyps. Ein interdisziplinärer Versuch im Bereich von Linguistik, Sozialwissenschaft und Psychologie (Athenäum, Frankfurt a. M., 1973)

10. O. Falafivka, Studia methodologica, 38, 208-213 (2014)

11. H. J. Heringer, Interkulturelle Kommunikation: Grundlagen und Konzepte (A. Francke Verlag, Tübingen und Basel, 2017)

12. C. Marinetti, Handb. of Transl. Studies, 2, 26-30 (2011)

13. D. Bachmann-Medick, Translation Studies, 2:1, 2-16 (2009). URL: https://www.tandfonline.com/doi/full/10.1080/14781700802496118?scroll=top\&need Access $=$ true

14. M. Kłańska, Daleko od Wiednia: Galicja w oczach pisarzy niemieckojęzycznych, 17721918 (Tow. Autorów i Wydawców Prac Naukowych Universitas, Cracow, 1991)

15. R. A. Mark, Galizien unter österreichischer Herrschaft. Verwaltung - Kirche Bevölkerung (Herder-Institut, Marburg, 1994)

16. S. Landmann, Mein Galizien. Das Land hinter den Karpaten (E. A. Herbig, München, 1995)

17. D. Hüchtker, Die Nationalisierung von Grenzen: Zur Konstruktion nationaler Identität in sprachlich gemischten Grenzregionen, 81-108 (2002)

18. M. Kłańska, Galizien als gemein. Literaturlandsch.: Beiträge des 2. Inssbrucker Symp. poln. und österr. Literaturwiss., 35-48 (1988)

19. Yu. Prokhasko, Histories of Literature: Collected Articles, 1-87 (2010)

20. Die großen Unbekannten: Die Ruthenen. URL:

https://ww1.habsburger.net/de/kapitel/die-grossen-unbekannten-die-ruthenen

21. K. E. Franzos, Vom Don zur Donau, I, 1-106 (1912)

22. K. E. Franzos, Ucrainica: Cultural Essays (translated by P. Rykhlo), 21-84 (2010)

23. A. von Guttry, Es war einmal Galizien..., 44-72 (2015)

24. A. von Guttry, Once upon a time there was Galicia... (translated by I. Klym, A. Paslavska), 45-73 (2015)

25. L. von Sacher-Masoch, Don Juan von Kolomea. URL: https://www.projektgutenberg.org/sacher-m/kolomea/kolomea.html 
26. M. Thiele, Medien und Stereotype: Konturen eines Forschungsfeldes (Transcript, Bielefeld, 2015)

27. L. von Sacher-Masoch, Venus in Furs (translated by N. Ivanychuk), 15-57 (2008)

28. Kleinrussen, Brockhaus' Kleines Konversations-Lexikon. URL:

http://www.zeno.org/Brockhaus-1911/A/Kleinrussen

29. S. Landmann, My Galicia. The Region behind Carpathian Mountains (translated by P. Rykhlo) (Knyhy-XXI, Chernivtsi, 2020)

30. L. von Sacher-Masoch, Es war einmal Galizien..., 74-82 (2015)

31. L. von Sacher-Masoch, Once upon a time there was Galicia... (translated by Kh. Velyka, Yu. Prokhasko), 75-83 (2015)

32. T. Lyaschenko, Funktionalstilistik der deutschen Sprache (Ivan Franko National University of Lviv, Lviv, 2010)

33. M. Kłańska, Problemfeld Galizien in deutschsprachiger Prosa 1846-1914 (Böhlau, Wien, 1991)

34. L. Venuti, The Translator's Invisibility: A History of Translation (Routledge, London, 1995) 